\title{
USE OF PROTECTION SCREEN IN CONVENTIONAL AVIARIES (CALIFORNIAN TYPE) FOR LAYING HENS
}

\author{
Dian Lourençoni ${ }^{1 *}$, Tadayuki Yanagi Junior ${ }^{2}$, Daniela D. de Oliveira ${ }^{3}$, Renato R. de Lima ${ }^{2}$, \\ Mariela R. da S. Pena ${ }^{4}$
}

${ }^{1 *}$ Corresponding author. Universidade Federal do Vale do São Francisco/ Juazeiro - BA, Brasil.
E-mail: dian.lourenconi@univasf.edu.br ORCID ID: https://orcid.org/0000-0003-1173-2381

\section{KEYWORDS}

Poultry farming, animal welfare, ambience, thermal comfort index.

\begin{abstract}
The objective of this work was to evaluate the thermal environment inside conventional cages for laying hens, with and without the use of protective screens. This research was conducted in two conventional cages (open cage), where each cage had half of its area surrounded by high density polyethylene mesh (HDPE) with a diameter of $2.0 \mathrm{~cm}$, and the other half was kept fully open. Hyline $W$-36 and Dekalb Brown laying hens were housed in these cages. The wind speed, dry bulb temperature $\left(\mathrm{t}_{\mathrm{db}}\right)$, black globe temperature, humidity index (BGHI), and enthalpy $(\mathrm{H})$ were analyzed. The results indicate that the use of the screen reduced the wind speed inside the cage by $0.22 \mathrm{~m} \mathrm{~s}^{-1}$. The presence of the screen affected $t_{\mathrm{db}}$, BGHI, and $\mathrm{H}$ in some of the evaluated periods evaluated, making these values higher than those of the treatment without screen. However, the obtained values are within or below the thermal comfort range for laying birds. Therefore, the use of HDPE screen in the cages altered their internal environment. However, it is not enough to hinder the thermal comfort of the housed animals.
\end{abstract}

\section{INTRODUCTION}

Owing to the occurrence of avian influenza viruses (H5N1 and H7N2), several studies related to avian biosafety have been conducted. The use of a screen to cover the entire outer perimeter of conventional cages (open cages) for laying hens has been proposed.

According to article 14 of Normative Instruction No. 56 (MAPA, 2007), superseded by Normative Instruction No. 36 of 2012 (MAPA, 2012), all commercial poultry establishments, in addition to other specifications, must be provided with protection to the external environment, with the installation of screens with a mesh size not greater than $2.54 \mathrm{~cm}$ (1.0 inch) to prevent the access of birds, domestic animals, and wild animals.

Many authors have pointed out that the thermal discomfort conditions are limiting factors for the development and production of animals with high genetic value (Jácome et al., 2007; Carcalho, 2012; Feize et al., 2012; Tinôco et al., 2014). In laying hens, thermal discomfort causes a series of consequences, which are closely linked to a lower growth rate, decrease in feed intake, change in feed conversion, higher water consumption, accelerated heart rate, decrease in egg production, and a higher incidence of soft-shelled eggs (Jácome et al., 2007; Furtado et al., 2011; Silva et al., 2012; Allahverdi et al., 2013; Kilic \& Simsek, 2013; Mack et al., 2013; Queiroz, 2014). In addition, according to Jácome et al. (2007) and Carvalho (2013), the thermal comfort of birds must be planned from the design of the facilities, choice of materials, and equipment used.

However, no studies regarding the influence of using protective screens on the thermal environment of conventional cages for commercial laying hens were found in the literature. Depending on the screen material, wire thickness, and mesh size, the air flow inside the cage may be reduced, thus increasing the thermal discomfort of the birds owing to the reduction of thermal changes between the internal and external environment.

Therefore, the purpose of this study was to evaluate the influence of the use of protective screens on the internal thermal environment of the facilities. Two conventional cages (Californian type) and two strains of laying hens (Hyline $W$ - 36 and Dekalb Brown) were used to in this study.

\footnotetext{
${ }^{2}$ Universidade Federal de Lavras/ Lavras - MG, Brasil.

${ }^{3}$ Aviário Santo Antônio/ Nepomuceno - MG, Brasil.

${ }^{4}$ Universidade Federal de Alfenas/ Poços de Caldas - MG, Brasil.

Received in: 6-1-2017

Accepted in: 12-19-2018
} 


\section{MATERIAL AND METHODS}

The experiment was carried out from June to November 2012, in a commercial egg production farm located in the southern state of Minas Gerais. The climate of the region according to Köppen is Cwa: a humid temperate climate, with a dry season in winter and a hot summer (Peel et al., 2007). The research was carried out in two identical cages of $7 \mathrm{~m} \mathrm{x} 120 \mathrm{~m}$ with a height of $2.50 \mathrm{~m}$ and an East-West orientation, covered with $6 \mathrm{~mm}$ thick asbestos cement roof, where each one had half of its area surrounded by screen and the other half was kept fully open (Figure 1). The protection screen used to cover a part of the cage was made of black-colored high-density polyethylene (HDPE), with a mesh of $2.0 \mathrm{~cm}$ diameter, which is compliant with Normative Instruction No56 (MAPA, 2007).

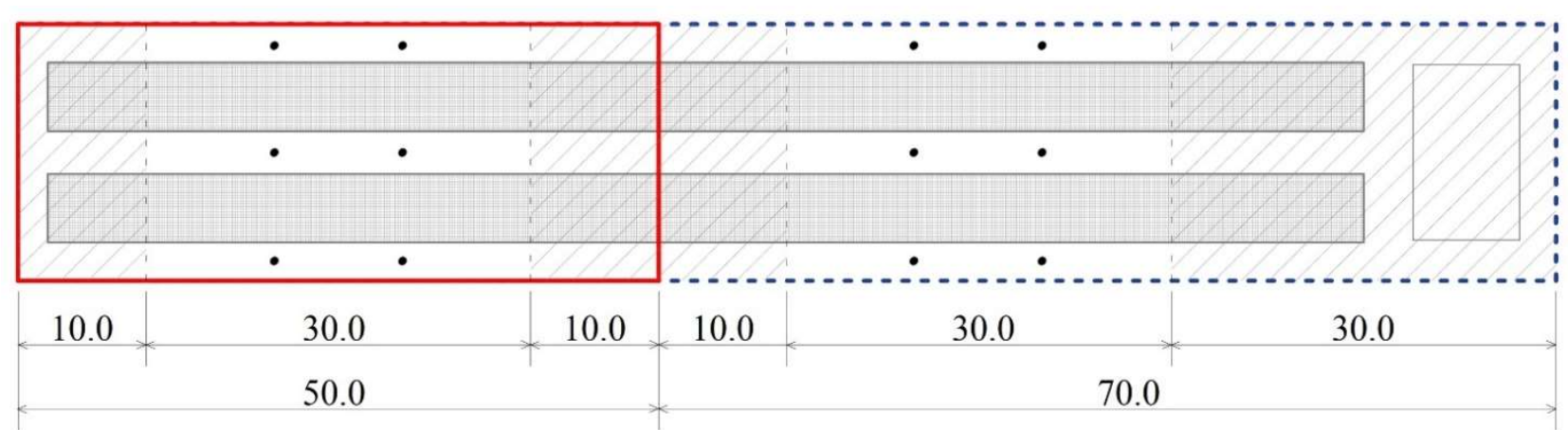

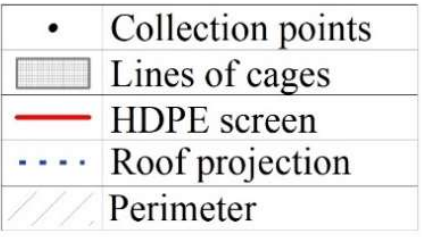

External collection point

FIGURE 1. Distribution of data collection points in the commercial aviaries for laying hens (Units: $\mathrm{m}$ ).

Hyline $W$-36 and Dekalb Brown laying hens were housed in the cages, aged from 71 weeks and 17 weeks at the beginning of the experiment, with each strain being allocated to a cage. During the experimental period, the birds received water and were fed ad libitum. The egg collections were performed twice a day, and the birds were subjected to 17 hours of light and 7 hours of darkness. The procedures adopted with the animals in this research were approved by the Committee of Ethics in Animal Experimentation of the Federal University of Lavras, protocol no. $026 / 12$.

The thermal environment was monitored simultaneously at six points distributed in each of the regions of the two cages, two in each corridor (central, north and south) (Figure 1). To evaluate the thermal environment, dry bulb temperature $\left(t_{d b}\right)$, dew point temperature $\left(t_{d p}\right)$, relative humidity $(\mathrm{RH})$, wind speed $(\mathrm{V})$, and black globe temperature $\left(\mathrm{t}_{\mathrm{g}}\right)$ were collected for the determination of the black globe temperature and humidity index (BGHI) proposed by Buffington et al. (1981) and the enthalpy $(\mathrm{H})$ proposed by Albright (1990) (equations 1 and 2, respectively).

$$
\begin{aligned}
& \text { BGHI }=t_{g}+0,36 t_{d p}+41,5 \\
& H=1,006 t_{d b}+W\left(2501+1,805 t_{d b}\right)
\end{aligned}
$$

Where,

$$
\begin{aligned}
& \mathrm{t}_{\mathrm{g}}=\text { black globe temperature }\left({ }^{\circ} \mathrm{C}\right) \text {, } \\
& \mathrm{t}_{\mathrm{dp}}=\text { dew point temperature }\left({ }^{\circ} \mathrm{C}\right) \text {, } \\
& \mathrm{t}_{\mathrm{db}}=\text { dry bulb temperature }\left({ }^{\circ} \mathrm{C}\right) \text {, and } \\
& \mathrm{W}=\text { mixing ratio }\left(\mathrm{kg}_{\text {water vapor }} \mathrm{kg}_{\text {dry air }}{ }^{-1}\right) \text {. }
\end{aligned}
$$

In turn, the mixing ratio can be calculated by means of [eq. (3)].

$$
\mathrm{W}=0,622\left(\mathrm{ea} / \mathrm{P}_{\mathrm{atm}}\right)
$$

Where,

$$
\begin{aligned}
& \text { ea }=\text { current water vapor pressure }(\mathrm{kPa}) \text {, and } \\
& \mathrm{P}_{\mathrm{atm}}=\text { local atmospheric pressure }(\mathrm{kPa}) .
\end{aligned}
$$

Recording sensors $\left( \pm 3 \%\right.$ reading accuracy, $\pm 1{ }^{\circ} \mathrm{C}$ temperature accuracy and $\pm 5 \%$ relative humidity accuracy) were used for the measurement of $t_{d b}, t_{d p}, R H$, and $t_{g}$. The data were collected every 2 hours, from 08:00 to 20:00 h. A hot wire anemometer (Extech Instruments, model 407123, $3.0 \%$ reading accuracy $+0.3 \mathrm{~m} \mathrm{~s}^{-1}$ and accuracy of \pm 0.3 $\mathrm{m} \mathrm{s}^{-1}$ ) was used to measure $\mathrm{V}$, and collections were made at every point, following the direction of travel corridors. The interval between the collection times at each point located in the cage, with and without screen, was less than one minute. This procedure allowed the statistical comparison of the previously mentioned variable in the areas with and without protection screens. All measurements were performed at the mean height of the cages $(1.0 \mathrm{~m})$.

For each cage, the experiment was carried out following the randomized block design (RBD), in a scheme of sub-divided plots. The two treatments were allocated in the plot, that is, the part of the cage covered with the screen and the area without screen. The corridor factor was allocated in the sub-plot, and the time factor was allocated in the sub-sub-plot, using data collected every 2 hours, from 08:00 to 20:00 $\mathrm{h}$, totaling seven collection times. The measurements were performed during 22 nonconsecutive days (measurements were performed once a week in each 
cage, during the experimental period), and each day was considered as a block. Statistical analyses were processed by the SAS software (2012).

The statistical model can be described according to equation 4 , where $y_{i j k l}$ is the value observed on screen $i$, corridor $\mathrm{k}$, and period 1 on day $\mathrm{j}$. In the equation, $\mu$ is a constant associated with each observation of $y_{i j k l}$; $t_{i}$ is the effect of screen $i$, where $i=$ with screen and without screen; $b_{j}$ is the effect of day $j$, with $j$ ranging from the 1 st to the 22 nd collection day; $\gamma_{\mathrm{ij}}$ is the experimental error in the plot; $\mathrm{c}_{\mathrm{k}}$ is the effect of corridor $\mathrm{k}$, where $\mathrm{k}=$ north, central, and south corridors; $\mathrm{tc}_{\mathrm{ik}}$ is the interaction between the screen and the corridor; $\varepsilon_{\mathrm{ijk}}$ is the experimental error in the sub-plot; $\mathrm{p}_{1}$ is the effect of period 1 , where $1=08: 00,10: 00,12: 00$, $14: 00,16: 00,18: 00$ and $20: 00 \mathrm{~h}$; tp $\mathrm{tp}_{\mathrm{il}}$ is the interaction between the screen and the period; $\mathrm{cp}_{\mathrm{kl}}$ is the interaction between the corridor and the period; $t_{c} p_{i k l}$ is the interaction between the screen, the corridor, and the period; and $\mathrm{e}_{\mathrm{ijkl}}$ is the experimental error.

$\mathrm{y}_{\mathrm{ijk} l}=\mu+\mathrm{t}_{\mathrm{i}}+\mathrm{b}_{\mathrm{j}}+\gamma_{\mathrm{ij}}+\mathrm{c}_{\mathrm{k}}+\mathrm{tc}_{\mathrm{ik}}+\varepsilon_{\mathrm{ijk}}+\mathrm{p}_{1}+\mathrm{tp}_{\mathrm{il}}+\mathrm{cp}_{\mathrm{k} l}+\mathrm{tcp}_{\mathrm{ikl}}+\mathrm{e}_{\mathrm{ijk} \mathrm{l}}$

\section{RESULTS AND DISCUSSION}

For $\mathrm{V}$, the significant difference $(\mathrm{p}<0.01$, test $\mathrm{F})$ in the screen treatment and in the corridor treatment were verified in the two cages (with Hyline W-36 and Dekalb Brown strains of hens).It was found that the use of the screen to surround the outer perimeter of the cage resulted in lower mean $\mathrm{V}$ values than those observed in the nonscreened area (Table 1). These results agree well with those observed by Coelho et al. (2015), which indicate that this may be detrimental to bird welfare, because ventilation is an efficient means of attenuating the thermal discomfort suffered by birds (Medeiros et al., 2005), owing to the increase of the heat transfer rate by convection. Lourençoni et al. (2015) observed that the use of cage screens for laying hens altered the levels of gases such as $\mathrm{CO}_{2}$ and $\mathrm{NH}_{3}$, probably because of the reduction of ventilation inside the cage.

TABLE 1. Mean values and root mean square error (RMSE) of wind speed ( $\left.\mathrm{m} \mathrm{s}^{-1}\right)$ in screened and nonscreened treatments inside the cages of Hyline $W-36$ and Dekalb Brown strains.

\begin{tabular}{|c|c|c|c|}
\hline \multirow{2}{*}{ Aviary } & \multicolumn{2}{|c|}{ Screen } & \multirow{2}{*}{ RMSE } \\
\hline & With & Without & \\
\hline Hyline $W$-36 & $0.53 \mathrm{~B}$ & $0.72 \mathrm{~A}$ & 0.30 \\
\hline Dekalb Brown & $0.41 \mathrm{~B}$ & $0.66 \mathrm{~A}$ & 0.29 \\
\hline
\end{tabular}

Means followed by distinct letters on the line, differ from one another by the $\mathrm{F}$ test at the $5 \%$ probability level.

Passini et al. (2013) and Oliveira et al. (2011) observed that the use of artificial ventilation was efficient in reducing the ambient temperature. The use of minimum ventilation results in lower values of gas concentration inside the cages, favoring the maintenance of air quality (Vigoderis et al., 2010). This constitutes further evidence of the importance of minimum ventilation within aviary cages.

Regarding the corridors, the highest speeds were observed in the north corridor, followed by the south corridor, and finally the central corridor, in both cages
(Table 2). The values observed in the northern corridor are because of the predominant wind from the northeast. The central corridor presented lower values of wind speed owing to the resistance to airflow caused by the batteries of cages installed on each side of the corridor. The results corroborate with those observed by Coelho et al. (2015), which evidenced a temperature gradient between the internal and external regions of the battery cages caused by, among other factors, reduced ventilation.

TABLE 2. Mean values and root mean square errors (RMSE) of the wind speed $\left(\mathrm{m} \mathrm{s}^{-1}\right)$ in the corridor plot inside the cages of the Hyline $W-36$ and Dekalb Brown strains of laying hens.

\begin{tabular}{ccccc}
\hline Aviary & & Screen & South & \multirow{2}{*}{ RMSE } \\
\cline { 2 - 4 } & North & Central & $0.65 \mathrm{~B}$ & 0.30 \\
Hyline $W-36$ & $0.84 \mathrm{~A}$ & $0.43 \mathrm{C}$ & $0.61 \mathrm{~B}$ & 0.29 \\
\hline Dekalb Brown & $0.69 \mathrm{~A}$ & $0.33 \mathrm{C}$ & 0.60
\end{tabular}

Means followed by different letters in the line differ from each other by the Tukey test at the $5 \%$ probability level.

In the cage in which the Hyline $W$-36 laying hens were housed for $t_{d b}$, significant difference $(p<0.01$, test $F)$ was observed in the interaction among the screen, the corridor, and the period. As can be seen in Table 3, the use of the screen caused the average air temperatures $\left(\mathrm{t}_{\mathrm{db}}\right)$ to be higher in the period between 08:00 and 10:00 $\mathrm{h}$ for the central corridor, compared to the part of the cage without the screen. For the northern corridor, the use of the screen caused the average values of $t_{d b}$ to be lesser than those for the treatment with screen considering that same period. This result can be explained by the period during which the study was conducted, winter. During winter, solar declination reaches a maximum value, and solar radiation directly affects the north corridor. In this case, the screen provided the reduction of solar radiation incident inside the cage. For the corridor treatment, the northern corridor presented higher mean temperature values in most of the periods evaluated. Ambient temperatures above $28{ }^{\circ} \mathrm{C}$ were recorded, which are above the ideal conditions of production of laying hens (Baêta \& Souza, 2010; Biaggioni et al., 2008). These results are also in agreement with those observed by Oliveira et al. (2011) and Coelho et al. (2015). 
TABLE 3. Average values of air temperature $\left({ }^{\circ} \mathrm{C}\right)$ in the treatments with and without screen between corridors during the period of evaluation inside the cage with Hyline $W$-36 laying hens.

\begin{tabular}{|c|c|c|c|c|}
\hline \multirow{2}{*}{ Period } & \multirow{2}{*}{ Screen } & \multicolumn{3}{|c|}{ Corridor } \\
\hline & & North & Central & South \\
\hline \multirow{2}{*}{ 08:00 } & Without & $18.2 \mathrm{a} \mathrm{B}$ & 16.7 a A & $17.1 \mathrm{a} \mathrm{AB}$ \\
\hline & With & $17.7 \mathrm{a} \mathrm{A}$ & $17.3 \mathrm{~b} \mathrm{~A}$ & $17.1 \mathrm{a} \mathrm{A}$ \\
\hline \multirow{2}{*}{ 10:00 } & Without & $24.5 \mathrm{a} B$ & $22.2 \mathrm{a} \mathrm{A}$ & $22.3 \mathrm{a} \mathrm{A}$ \\
\hline & With & $24.0 \mathrm{a} \mathrm{B}$ & $22.8 \mathrm{~b} \mathrm{~A}$ & $22.3 \mathrm{a} \mathrm{A}$ \\
\hline \multirow{2}{*}{$12: 00$} & Without & $28.7 \mathrm{~b} \mathrm{~B}$ & $26.8 \mathrm{a} \mathrm{A}$ & $26.4 \mathrm{a} \mathrm{A}$ \\
\hline & With & $28.1 \mathrm{a} \mathrm{B}$ & $27.1 \mathrm{a} \mathrm{AB}$ & $26.3 \mathrm{a} \mathrm{A}$ \\
\hline \multirow{2}{*}{$14: 00$} & Without & $31.0 \mathrm{~b} \mathrm{~B}$ & 28.7 a A & $28.1 \mathrm{a} \mathrm{A}$ \\
\hline & With & 30.3 a B & $29.0 \mathrm{a} \mathrm{A}$ & 27.9 a A \\
\hline \multirow{2}{*}{$16: 00$} & Without & 30.6 b B & $28.3 \mathrm{a} \mathrm{A}$ & $27.5 \mathrm{a} A$ \\
\hline & With & 29.8 a C & 28.5 a B & $27.4 \mathrm{a} \mathrm{A}$ \\
\hline \multirow{2}{*}{ 18:00 } & Without & $23.0 \mathrm{a} A B$ & $23.5 \mathrm{a} B$ & $22.3 \mathrm{a} \mathrm{A}$ \\
\hline & With & 22.9 a A & $23.2 \mathrm{a} \mathrm{A}$ & $22.2 \mathrm{a} \mathrm{A}$ \\
\hline \multirow{2}{*}{ 20:00 } & Without & $18.8 \mathrm{a} \mathrm{A}$ & $19.6 \mathrm{a} \mathrm{A}$ & $18.9 \mathrm{a} \mathrm{A}$ \\
\hline & With & 18.9 a A & $19.5 \mathrm{a} \mathrm{A}$ & $18.8 \mathrm{a} \mathrm{A}$ \\
\hline
\end{tabular}

Means followed by different letters, upper case in the row and lowercase in the column, differ by the Tukey test at the $5 \%$ probability level. Root mean square error $($ RMSE $)=0.67$.

Temperatures above ideal conditions cause a decrease in feed consumption and an increase in water intake on laying hens, and may negatively influence the percentage of laying and weight of eggs (Costa et al., 2012; Deng et al., 2012; Vercese et al., 2012; Kilic \& Simsek, 2013; Mack et al., 2013; Guimarães et al., 2014; Oliveira et al., 2014).

For the $t_{d b}$, the significant difference $(p<0.01$, test $F$ ) in the interaction between the screen and the period was verified in the cage with the Dekalb Brown strain. As can be seen in Table 4, the use of the screen caused the mean values of the $t_{\mathrm{db}}$ to be similar for the treatments with and without screen, except at 18:00 and 20:00 h. During this period, the section surrounded by the screen had higher $t_{d b}$ values (Tukey test, $\mathrm{p}>0.05$ ), possibly owing to the lower air circulation caused by the screen, which is also in accordance with the work developed by Lourençoni et al. (2015). The thermal oscillations followed a pattern of increase of the $t_{d b}$ in the middle of the day and decrease after 16:00 h. Despite these variations, the $t_{d b}$ remained within the zone of thermal comfort for the laying hens (Biaggioni et al., 2008; Baêta \& Souza, 2010). These results corroborate the work done by Biaggioni et al. (2008), who evaluated different types of facilities for commercial laying hens and found oscillations similar to those found in this work throughout the day.

TABLE 4. Average values of air temperature $\left({ }^{\circ} \mathrm{C}\right)$ in the treatments with and without screen during the period of evaluation inside the cage with laying hens of the Dekalb Brown strain.

\begin{tabular}{ccc}
\hline \multirow{2}{*}{ Period } & \multicolumn{2}{c}{ Use of screen } \\
\cline { 2 - 3 } & With & Without \\
\hline $\mathbf{1 0 : 0 0}$ & $18.4 \mathrm{a} \mathrm{A}$ & $18.2 \mathrm{a} \mathrm{A}$ \\
$\mathbf{1 2 : 0 0}$ & $22.2 \mathrm{~b} \mathrm{~A}$ & $22.1 \mathrm{~b} \mathrm{~A}$ \\
$\mathbf{1 4 : 0 0}$ & $25.5 \mathrm{c} \mathrm{A}$ & $25.3 \mathrm{c} \mathrm{A}$ \\
$\mathbf{1 6 : 0 0}$ & $27.0 \mathrm{c} \mathrm{A}$ & $26.8 \mathrm{c} \mathrm{A}$ \\
$\mathbf{1 8 : 0 0}$ & $26.4 \mathrm{c} \mathrm{A}$ & $26.4 \mathrm{c} \mathrm{A}$ \\
$\mathbf{2 0 : 0 0}$ & $22.3 \mathrm{~b} \mathrm{~B}$ & $21.8 \mathrm{~b} \mathrm{~A}$ \\
\hline
\end{tabular}

Means followed by different letters, upper case in the row and lowercase in the column, differ by the Tukey test at the $5 \%$ probability level. Root mean square error $(\mathrm{RMSE})=0.65$.

When evaluating the BGHI for the Hyline $W-36$ laying hens, the significant difference $(\mathrm{p}<0.01$, test $\mathrm{F})$ in the interaction among the screen, the corridor, and the period was verified. The use of the screen resulted in higher average BGHI values in the period between 14:00 and 16:00 $\mathrm{h}$ for the central corridor; the opposite effects were observed in the north corridor (Table 5). This result can also be explained by the solar declination owing to the period during which the research was carried out. With regard to the corridor treatment, the north presented higher average BGHI values in the period between 08:00 to 16:00 h.
Overall, the cage remained in adequate thermal condition throughout the period in the central and the south corridor, except between 14:00 and 16:00 $\mathrm{h}$ in the south corridor. In the northern corridor, only in the 08:00, 18:00, and 20:00 $\mathrm{h}$ periods, the BGHI values remained below the upper limit of comfort according to the classification proposed by Baêta \& Souza (2010), who indicate that a BGHI of up to 74 is considered a safe environment and between 74 and 78 require some care. This result corroborates the work carried out by Furtado et al. (2011), in which the BGHI was above the recommended levels from 9:00 to 17:00 h. 
TABLE 5. Mean values of the black globe temperature and humidity index (BGHI) in the treatments with and without screen between corridors during the evaluation period inside the cage of the Hyline $W$-36 strain.

\begin{tabular}{|c|c|c|c|c|}
\hline \multirow{2}{*}{ Period } & \multirow{2}{*}{ Screen } & \multicolumn{3}{|c|}{ Corridor } \\
\hline & & North & Central & South \\
\hline \multirow{2}{*}{ 08:00 } & Without & $68.5 \mathrm{a} B$ & $62.8 \mathrm{a} \mathrm{A}$ & $64.7 \mathrm{a} \mathrm{A}$ \\
\hline & With & $68.1 \mathrm{a} \mathrm{B}$ & $63.1 \mathrm{a} \mathrm{A}$ & $63.2 \mathrm{a} \mathrm{A}$ \\
\hline \multirow{2}{*}{ 10:00 } & Without & 76.2 a B & $68.5 \mathrm{a} \mathrm{A}$ & 69.5 a A \\
\hline & With & 75.5 a B & $69.2 \mathrm{a} \mathrm{A}$ & 69.0 a A \\
\hline \multirow{2}{*}{$12: 00$} & Without & 80.8 a B & 72.7 a A & 73.6 a A \\
\hline & With & 79.3 a B & 73.5 a A & $73.4 \mathrm{a} \mathrm{A}$ \\
\hline \multirow{2}{*}{$14: 00$} & Without & $84.0 \mathrm{~b}$ B & $73.5 \mathrm{a} \mathrm{A}$ & 75.4 a A \\
\hline & With & 81.6 a B & $75.5 \mathrm{~b} \mathrm{~A}$ & $75.0 \mathrm{a} \mathrm{A}$ \\
\hline \multirow{2}{*}{$16: 00$} & Without & $82.8 \mathrm{~b} \mathrm{~B}$ & $72.3 \mathrm{a} \mathrm{A}$ & 74.7 a A \\
\hline & With & $80.1 \mathrm{a} B$ & $75.0 \mathrm{~b} \mathrm{~A}$ & $74.3 \mathrm{a} \mathrm{A}$ \\
\hline \multirow{2}{*}{ 18:00 } & Without & $69.3 \mathrm{a} A$ & $70.1 \mathrm{a} \mathrm{A}$ & 69.8 a A \\
\hline & With & $70.3 \mathrm{a} \mathrm{A}$ & 70.8 a $\mathrm{A}$ & 69.6 a A \\
\hline \multirow{2}{*}{ 20:00 } & Without & $63.8 \mathrm{a} \mathrm{A}$ & $66.0 \mathrm{a} \mathrm{A}$ & $65.3 \mathrm{a} \mathrm{A}$ \\
\hline & With & $65.4 \mathrm{a} \mathrm{A}$ & $66.3 \mathrm{a} A$ & $65.4 \mathrm{a} \mathrm{A}$ \\
\hline
\end{tabular}

Means followed by different letters, upper case in the row and lowercase in the column, differ by the Tukey test at the $5 \%$ probability level. Root mean square error $($ RMSE) $=2.05$.

In relation to the $\mathrm{BGHI}$, for the cage with the Dekalb Brown strain, the significant difference $(p<0.01$, test $F)$ between the screen and the period, and between the corridor and period interactions, was verified. The use of the screen resulted in mean BGHI values similar to the treatment without screen, except in the 20:00 h period, where this value was higher in the screen treatment (Table 6). In relation to the corridor treatment, the north presented higher average BGHI values in the period from 10:00 to $16: 00 \mathrm{~h}$ (Table 7). This result can also be explained by the time during which the research was conducted, winter. During winter, solar declination reaches its maximum, and the solar radiation is directly incident on the north corridor. Based on the classification proposed by Baêta \& Souza (2010), which indicate that an BGHI of up to 74 is considered a safe environment and between 74 and 78 require certain care, in general, the cage remained in adequate thermal condition throughout the period in the central and the south corridor, with the exception of the $14: 00 \mathrm{~h}$ period for the south corridor. Regarding the northern corridor, only in the periods of 8:00, 18:00, and 20:00 h, the BGHI values remained below the upper comfort limit. This result is also in accordance with the work carried out by Furtado et al. (2011).

TABLE 6. Mean values of the black globe temperature and humidity index (BGHI) in the treatments with and without screen during the evaluation period inside the cage with laying hens of the Dekalb Brown strain.

\begin{tabular}{ccc}
\hline \multirow{2}{*}{ Period } & \multicolumn{2}{c}{ Screen usage } \\
\cline { 2 - 3 } & With & Without \\
$\mathbf{1 0 : 0 0}$ & $65.2 \mathrm{a} \mathrm{A}$ & $65.4 \mathrm{a} \mathrm{A}$ \\
$\mathbf{1 2 : 0 0}$ & $70.8 \mathrm{~b} \mathrm{~A}$ & $70.5 \mathrm{~b} \mathrm{~A}$ \\
$\mathbf{1 4 : 0 0}$ & $74.4 \mathrm{c} \mathrm{A}$ & $73.8 \mathrm{c} \mathrm{A}$ \\
$\mathbf{1 6 : 0 0}$ & $76.0 \mathrm{c} \mathrm{A}$ & $76.2 \mathrm{c} \mathrm{A}$ \\
$\mathbf{1 8 : 0 0}$ & $75.1 \mathrm{c} \mathrm{A}$ & $75.2 \mathrm{c} \mathrm{A}$ \\
$\mathbf{2 0 : 0 0}$ & $70.1 \mathrm{~b} \mathrm{~A}$ & $69.1 \mathrm{~b} \mathrm{~A}$ \\
\hline
\end{tabular}

Means followed by different letters, upper case in the row and lowercase in the column, differ by the Tukey test at the $5 \%$ probability level. Root mean square error $($ RMSE) $=2.00$.

TABLE 7. Mean values of the black globe temperature and humidity index (BGHI) in the corridor, factor during the evaluation period inside the cage with the Dekalb Brown strain.

\begin{tabular}{|c|c|c|c|}
\hline \multirow{2}{*}{ Period } & \multicolumn{3}{|c|}{ Corridor } \\
\hline & North & Central & South \\
\hline 08:00 & 66.4 a A & $64.3 \mathrm{a} \mathrm{A}$ & $65.1 \mathrm{a} \mathrm{A}$ \\
\hline 10:00 & $74.1 \mathrm{~b} \mathrm{~B}$ & $68.4 \mathrm{~b} \mathrm{~A}$ & $69.5 \mathrm{~b} \mathrm{~A}$ \\
\hline $12: 00$ & 77.7 c B & $71.7 \mathrm{c} \mathrm{A}$ & $72.8 \mathrm{c} \mathrm{A}$ \\
\hline 14:00 & 80.4 c B & $73.4 \mathrm{c} \mathrm{A}$ & 74.4 c A \\
\hline 16:00 & 78.9 с B & $72.9 \mathrm{~cd} \mathrm{~A}$ & $73.8 \mathrm{c} \mathrm{A}$ \\
\hline 18:00 & $69.3 \mathrm{a} \mathrm{A}$ & $70.0 \mathrm{bd} \mathrm{A}$ & $69.5 \mathrm{~b} \mathrm{~A}$ \\
\hline 20:00 & $65.1 \mathrm{a} \mathrm{A}$ & $66.6 \mathrm{ab} \mathrm{A}$ & $65.3 \mathrm{a} \mathrm{A}$ \\
\hline
\end{tabular}

Means followed by distinct letters, uppercase in the row and lowercase in the column, differ by the Tukey test at the 5\% probability level. Root mean square error $(\mathrm{RMSE})=2.00$. 
For the enthalpy $(\mathrm{H})$, the significant difference $(\mathrm{p}<0.01$, test $\mathrm{F}$ ) in the interaction among the screen, the corridor and the period was verified in both cages, and in the cage with the Hyline $W-36$ strain, the use of the screen resulted in mean enthalpy values $(H)$ higher than those found in the no-screen area for the central corridor during all periods of the day and for the northern corridor in the periods of 8:00, 10:00, 12:00, 18:00, and 20:00 h (Table 8). However, the observed values of $\mathrm{H}$ were lower than those recommended by Barbosa Filho et al. (2007) for laying hens, which ranged from 64 and $70 \mathrm{~kJ} k g$ for dry air ${ }^{-1}$ and by Vieira et al. (2010), whose comfort range varies between 58 and $68.8 \mathrm{~kJ} \mathrm{~kg}$ for dry air $^{-1}$.

TABLE 8. Mean values of enthalpy ( $\mathrm{kJ} \mathrm{kg}$ of dry $\left.\mathrm{air}^{-1}\right)$ in the treatments with and without screen in corridors throughout the evaluation period inside the cages of the Hyline $W-36$ and Dekalb Brown strains.

\begin{tabular}{|c|c|c|c|c|c|c|c|}
\hline \multirow{3}{*}{ Period } & \multirow{3}{*}{ Screen } & \multicolumn{3}{|c|}{ Hyline $W-36(\mathrm{RMSE}=1.07)$} & \multicolumn{3}{|c|}{ Dekalb Brown (RMSE = 1.25) } \\
\hline & & \multicolumn{3}{|c|}{ Corridor } & \multicolumn{3}{|c|}{ Corridor } \\
\hline & & North & Central & South & North & Central & South \\
\hline \multirow{2}{*}{ 08:00 } & Without & $42.1 \mathrm{a} \mathrm{A}$ & $42.0 \mathrm{a} \mathrm{A}$ & $43.0 \mathrm{a} \mathrm{A}$ & 45.6 a $\mathrm{A}$ & 46.4 a A & 46.8 a A \\
\hline & With & $45.4 \mathrm{~b} \mathrm{~B}$ & $43.9 \mathrm{~b} \mathrm{AB}$ & 42.8 a A & $49.2 \mathrm{~b} \mathrm{~B}$ & $48.4 \mathrm{~b} \mathrm{AB}$ & 46.5 a A \\
\hline \multirow{2}{*}{ 10:00 } & Without & $48.3 \mathrm{a} \mathrm{A}$ & 48.2 a A & 51.0 a B & 49.8 a A & 49.8 a A & $52.0 \mathrm{a} A$ \\
\hline & With & $51.3 \mathrm{~b} \mathrm{~A}$ & $50.9 \mathrm{~b} \mathrm{~A}$ & 50.7 a A & $53.3 \mathrm{~b} \mathrm{~A}$ & $52.7 \mathrm{~b} \mathrm{~A}$ & $51.5 \mathrm{a} A$ \\
\hline \multirow{2}{*}{$12: 00$} & Without & $51.3 \mathrm{a} \mathrm{A}$ & $51.2 \mathrm{a} \mathrm{A}$ & 55.4 a B & $52.1 \mathrm{a} \mathrm{A}$ & 51.9 a A & 55.7 a B \\
\hline & With & $53.3 \mathrm{~b} \mathrm{~A}$ & $53.7 \mathrm{~b} \mathrm{~A}$ & $55.2 \mathrm{a} \mathrm{A}$ & $54.8 \mathrm{~b} \mathrm{~A}$ & $55.0 \mathrm{~b} \mathrm{~A}$ & 55.5 a A \\
\hline \multirow{2}{*}{$14: 00$} & Without & $53.0 \mathrm{a} \mathrm{A}$ & $51.3 \mathrm{a} A$ & 55.9 a B & $52.8 \mathrm{a} A$ & $52.1 \mathrm{a} \mathrm{A}$ & 56.0 a B \\
\hline & With & $53.5 \mathrm{a} \mathrm{A}$ & $54.0 \mathrm{~b} \mathrm{AB}$ & 55.7 a B & $54.6 \mathrm{~b} \mathrm{~A}$ & $54.6 \mathrm{~b} \mathrm{~A}$ & 55.7 a A \\
\hline \multirow{2}{*}{ 16:00 } & Without & $52.5 \mathrm{a} \mathrm{B}$ & 50.5 a A & $55.1 \mathrm{a} \mathrm{C}$ & $52.0 \mathrm{a} \mathrm{A}$ & 50.9 a $\mathrm{A}$ & 54.7 a B \\
\hline & With & $52.5 \mathrm{a} \mathrm{A}$ & $53.1 \mathrm{~b} \mathrm{AB}$ & 54.8 a B & $53.2 \mathrm{~b} \mathrm{~A}$ & $53.5 \mathrm{~b} \mathrm{~A}$ & 54.6 a A \\
\hline \multirow{2}{*}{ 18:00 } & Without & $45.3 \mathrm{a} \mathrm{A}$ & 48.6 a B & 49.4 a B & $46.5 \mathrm{a} \mathrm{A}$ & 49.3 a B & $49.2 \mathrm{a} \mathrm{B}$ \\
\hline & With & $49.0 \mathrm{~b} \mathrm{~A}$ & 49.7 b A & 49.3 a A & $50.3 \mathrm{~b} \mathrm{~A}$ & $51.4 \mathrm{~b} \mathrm{~A}$ & 49.3 a A \\
\hline \multirow{2}{*}{ 20:00 } & Without & $41.4 \mathrm{a} \mathrm{A}$ & 44.2 a B & 44.5 a B & $43.2 \mathrm{a} \mathrm{A}$ & 45.6 a B & $44.7 \mathrm{a} \mathrm{AB}$ \\
\hline & With & $44.9 \mathrm{~b} \mathrm{~A}$ & $45.4 \mathrm{~b} \mathrm{~A}$ & $44.2 \mathrm{a} \mathrm{A}$ & $47.0 \mathrm{~b} \mathrm{AB}$ & $47.8 \mathrm{~b} \mathrm{~B}$ & $45.2 \mathrm{a} \mathrm{A}$ \\
\hline
\end{tabular}

Means followed by distinct letters, uppercase in the row and lowercase in the column, differ by the Tukey test at the $5 \%$ probability level.

On the contrary, for the cage with the Dekalb Brown strain, the use of the screen resulted in mean $\mathrm{H}$ values higher than those found in the section without the screen for the north and central corridors during all periods of the day (Table 8). However, the values were lower than those recommended by Barbosa Filho et al. (2007) and Vieira et al. (2010) for laying hens, which range between 64 and 70 $\mathrm{kJ} \mathrm{kg}$ for dry air ${ }^{-1}$.

\section{CONCLUSIONS}

The use of HDPE screen of $2.0 \mathrm{~cm}$ diameter to surround the outer perimeter of conventional cages (Californian type) reduced the internal wind speed by 0.22 $\mathrm{m} \mathrm{s}^{-1}$. The presence of the screen affected $t_{\mathrm{db}}$, BGHI, and enthalpy in some evaluated periods, generally causing these values to be higher than those of the treatment without the screen. However, the values are either within or below the comfort range. Under conditions of direct solar radiation on one side of the cage, the reduction of $t_{d b}, B G H I$, and $\mathrm{H}$ is verified, given that the screen provides mitigation of incident solar radiation inside the cage.

Despite the use of the screen in the outer perimeter of the cage to reduce the wind speed inside, it was verified that this reduction did not cause thermal limitations that made its use unfeasible.

\section{ACKNOWLEDGMENTS}

The authors would like to thank FAPEMIG, CAPES, CNPq, and Santo Antonio Aviary (Aviário Santo Antônio ASA) for their support in carrying out this research.

\section{REFERENCES}

Allahverdi A, Feizi A, Takhtfooladi HA, Nikpiran H (2013) Effects of heat stress on acid-base imbalance, plasma calcium concentration, egg production and egg quality in commercial layers. Global Veterinaria 10(2):203-207.

Albright LD (1990) Environment control for animals and plants. St. Joseph: American Society of Agricultural Engineers Michigan. ASAE, 453p (Textbook, 4)

Baêta FC, Souza CF (2010) Ambiência em edificações rurais - conforto animal. Viçosa, $\mathrm{MG}, 246 \mathrm{p}$.

Barbosa Filho JAD, Silva IJO, Silva MAN, Silva CJM (2007) Avaliação dos comportamentos de aves poedeiras utilizando sequência de imagens. Engenharia Agrícola 27:93-99.

Biaggioni MAM, Mattos JM, Jasper SP, Targa LA (2008) Desempenho térmico de aviário de postura acondicionado naturalmente. Semina: Ciências Agrárias 29:961-971.

Buffington DE, Collasso-Arocho A, Canton GH, Pit D (1981) Black globe-humidity index (BGHI) as comfort equation for dairy cows. Transactions of the ASAE 24(3):711-0714.

Carcalho LSS (2012) Nutrição de poedeiras em clima quente. Revista Científica Eletrônica de Medicina Veterinária 18:1-15. 
Carvalho HG (2013) Materiais de cobertura e suas associações a forros e materiais isolantes no ambiente térmico de protótipos abertos e fechados com vistas a produção de frangos de corte em clima quente. Tese Doutorado, Universidade Federal de Viçosa.

Coelho DJR, Tinoco IFF, Vieira MFA, Mendes MASA, Sousa FC, França LGF (2015) Mapeamento do ambiente térmico de aviários de postura abertos em sistema vertical de criação. Revista Brasileira de Engenharia Agrícola e Ambiental 19:996-1004.

Costa EMS, Dourado LRB, Merval RR (2012) Medidas para avaliar o conforto térmico em aves. Publicações em Medicina Veterinária e Zootecnia 6:2012-2018.

Deng W, Dong XF, Tong JM, Zhang Q (2012) The probiotic Bacillus licheniformis ameliorates heat stressinduced impairment of egg production, gut morphology, and intestinal mucosal immunity in laying hens. Poultry science 91(3):575-582.

Feize A, Shahbazi M, Taifebagerlu J, Haghigat A (2012) Effect of heat stress (HS) on production of Hy-line layers. Research Journal of Biological Sciences 7(5):206-208.

Furtado DA, Mota JKM, Nascimento JWB, Silva VR, Tota LCA (2011) Produção de ovos de matrizes pesadas criadas sob estresse térmico. Revista Brasileira de Engenharia Agricola e Ambiental-Agriambi 15(7):748-753.

Guimarães MCC, Furtado DA, Nascimento JWB, Tota LCA, Silva CM, Lopes KBP (2014) Efeito da estação do ano sobre o desempenho produtivo de codornas no semiárido paraibano. Revista Brasileira de Engenharia Agricola e Ambiental-Agriambi 18(2):231-237.

Jácome IMTD, Furtado DA, Leal AF, Silva JHV, Moura JFP (2007) Avaliação de índices de conforto térmico de instalações para poedeiras no nordeste do Brasil Evaluation of thermal comfort indexes for laying-hen houses in the northeast of Brazil. Revista Brasileira de Engenharia Agrícola e Ambiental-Agriambi 11(5):527-531.

Kilic I, Simsek E (2013) The effects of heat stress on egg production and quality of laying hens. Journal of Animal and Veterinary Advances 12(1):42-7.

Lourençoni D, Yanagi Junior T, Oliveira DD, Campos AT, Lima RR (2015) Environmental conditions in a conventional screened poultry shed. Engenharia Agrícola 35(1):1-10.

Mack LA, Felver-Gant JN, Dennis RL, Cheng HW (2013) Genetic variations alter production and behavioral responses following heat stress in 2 strains of laying hens. Poultry science 92(2):285-294.

MAPA - Ministério da Agricultura, Pecuária e Abastecimento (2007) Instrução Normativa n.56. Procedimentos para registro, fiscalização e controle de estabelecimentos avícolas de reprodução e comerciais. Brasília, 23p.

MAPA - Ministério da Agricultura, Pecuária e Abastecimento (2012) Instrução Normativa n.36.

Procedimentos para registro, físcalização e controle de estabelecimentos avícolas de reprodução e comerciais. Brasília, 7p.
Medeiros CM, Baêta FC, Oliveira RFM, Tinôco IFF, Albino LFTA, Cecon PR (2005) Efeitos da temperatura, umidade relativa e velocidade do ar em frangos de corte. Engenharia na Agricultura 13(4):277-286.

Oliveira DL, Nascimento JWB, Camerini NL, Silva RC, Furtado DA, Araujo TGP (2014) Desempenho e qualidade de ovos de galinhas poedeiras criadas em gaiolas enriquecidas e ambiente controlado. Revista Brasileira de Engenharia Agricola e Ambiental-Agriambi 18(11):11861191.

Oliveira EL, Gomes FA, Silva CC, Delgado RC, Ferreira JB (2011) Desempenho, características fisiológicas e qualidade de ovos de poedeiras Isa Brown criadas em diferentes sistemas de produção no Vale do Juruá-Acre. Enciclopédia Biosfera 7(13):339-347.

Passini R, Araújo MAG, Yasuda VM, Almeida EA (2013) Intervenção ambiental na cobertura e ventilação artificial sobre índices de conforto para aves de corte. Revista Brasileira de Engenharia Agricola e Ambiental-Agriambi 17(3):333-338.

Peel MC, Finlayson BL, Mcmahon TA (2007) Updated world map of the Köppen-Geiger climate classification. Hydrology and earth system sciences discussions 4(2):439473.

SAS Institute (2012) SAS/STATTM SAS user's guide for windows environment. 9.3 ed. Cary, SAS Institute, $9.3 \mathrm{ed}$.

Queiroz JPAF (2014) Daily variations in the thermoregulatory bahaviors of naked neck broilers in an equatorial semi-arid environment. International journal of biometeorology 58(6):1259-1264.

Silva RC, Nascimento JD, Oliveira DL, Camerini NL, Furtado DA (2012) Força de ruptura da casca do ovo em função das temperaturas da água e do ambiente. Revista Educação Agrícola Superior 27:13-18.

Tinôco IFF, Souza CF, Baêta FC, Coelho DJR, Mendes MASA (2014) Ambiencia e Instalações na Avicultura de Postura Brasileira - Avanços e Perspectivas. Animal Busineess Brasil 4(14):6-9.

Vercese F, Garcia EA, Sartori JR, Pontes Silva A de P, Faitarone ABG, Berto DA, Molino A de B, Pelícia K (2012) Performance and egg quality of japanese quails submitted to cyclic heat stress. Brazilian Journal of Poultry Science 14(1):37-41.

Vieira FMC, Nazareno AC, Silva IJO (2010) Tabela de entalpia para poedeiras. NUPEA - ESALQ - USP.

Available in:

http://www.nupea.esalq.usp.br/noticias/producao/c9387_2 0100713.pdf. Accessed: Sep 21, 2015.

Vigoderis RB, Cordeiro MB, Tinôco IDFF, Menegali I, Souza Júnior JD, Holanda MD (2010) Avaliação do uso de ventilação mínima em galpões avícolas e de sua influência no desempenho de aves de corte no período de inverno. Revista Brasileira de Zootecnia 39(6):1381-1386. 